\title{
Oligocene-Miocene carbonates in the Reed Bank area, South China Sea, and their tectono-sedimentary evolution
}

\author{
Weiwei Ding $\cdot$ Jiabiao Li $\cdot$ Congzhi Dong $\cdot$ \\ Yinxia Fang
}

Received: 9 April 2014/ Accepted: 22 August 2014/Published online: 4 September 2014

(C) The Author(s) 2014. This article is published with open access at Springerlink.com

\begin{abstract}
We have analyzed two recently acquired multichannel seismic profiles across the Reed Bank area, South China Sea. A detailed seismic interpretation coupled with drilling data has proved the occurrence of a wide carbonate platform, developed between the Late Oligocene and the Early Miocene (32-20 Ma). The top of these carbonates is an important regional unconformity, corresponding to a strong and continuous seismic reflector. An age of about $20 \mathrm{Ma}$ is inferred for this reflector, acting as a regional unconformity marking the cessation of seafloor spreading with an erosional/non-depositional hiatus, spanning 3 or 4 m.y. The time interval during which the carbonate platforms formed is concurrent with the opening of the South China Sea. The reconstruction of the tectonic subsidence in this area has shown a decrease in rate of subsidence during the drifting stage (32-17 Ma), indicating that the whole Reed Bank area was in a tectonically stable and shallow water environment for more than 10 m.y., favoring the development of shallow water carbonates. With a sharply increased subsidence rate after the end of spreading (17 Ma) and a continuously increased sea level, the carbonate platforms were drowned and died, except some structural highs with reef buildups, where the carbonate sedimentation continued to Middle Miocene. We suggest that delayed tectonic subsidence in Reed Bank area might have been related to a secondary mantle convection under the rift lasting more than about 10 m.y.
\end{abstract}

W. Ding $(\varangle) \cdot$ J. Li $~$ C. Dong · Y. Fang

The Second Institute of Oceanography, State Oceanic

Administration, Hangzhou, China

e-mail: wwding@sio.org.cn; wwding@gmail.com

J. Li

e-mail: jbli@sio.org.cn
Keywords Carbonates - Reed Bank area . Tectonic subsidence - Mantle convection . Sea level changes - South China Sea

\section{Introduction}

Shallow water carbonates, including carbonate platform and reefs, are widely distributed in the middle and low latitude passive margins worldwide (Bathurst 1971; Lees and Buller 1972; Wilson 1975; Reading 1978). As a feature in tropical and sub-tropical depositional settings, carbonate deposition could act as an indication of tectonic subsidence, sea level changes, environmental factors and terrigenous sediment input (Schlager and Camber 1986; Schlager 1989; Ma et al. 2011; Franke et al. 2013; Ding et al. 2014). They can also be important for hydrocarbon exploration, because some reefs and carbonate platforms are highly porous and host nearly one half of the world's hydrocarbon reserves, containing some of the largest aquifers on the Earth (Sun and Esteban 1994; Groetsch et al. 1998; Wu et al. 2008; Sattler et al. 2009). Due to geological and geophysical data acquired in the last decades, Cenozoic shallow water carbonates in the South China Sea have been well documented on its (1) detailed seismic features, stratigraphic architecture, and controlling factors in local regions, such as the northern rim of the Dongsha Islands (Tyrell and Christian 1992); the western Pearl River Mouth Basin (Sattler et al. 2009); the Qiongdongnan Basin (Wu et al. 2008; Ma et al. 2011) in the northern continental margin of the South China Sea; the Phu Khanh Basin (Fyhn et al. 2009), the offshore of central Vietnam (Fyhn et al. 2013) in the western continental margin; the Dangerous Grounds (Ding et al. 2013; Franke et al. 2013) in the southern continental margin; and (2) 


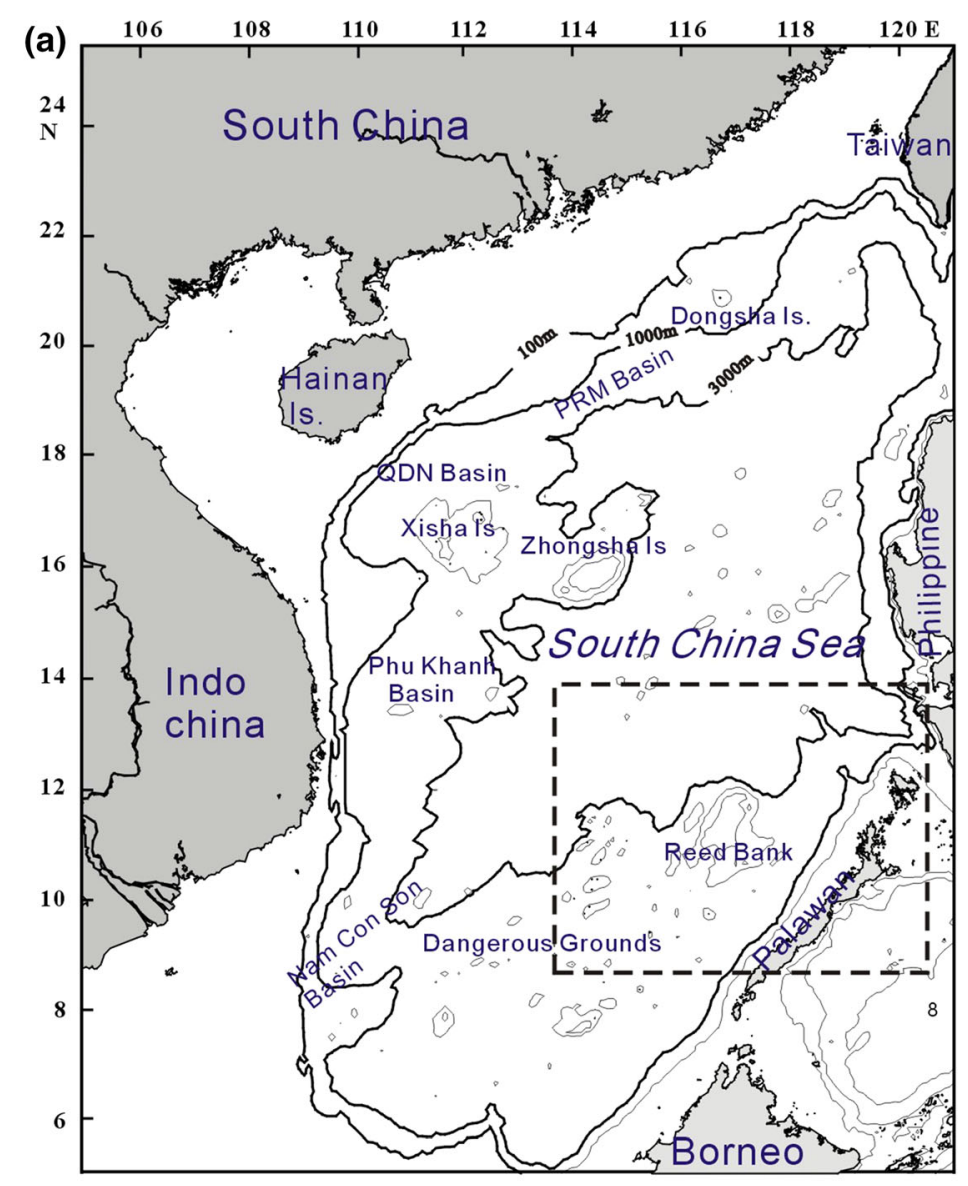

(b)

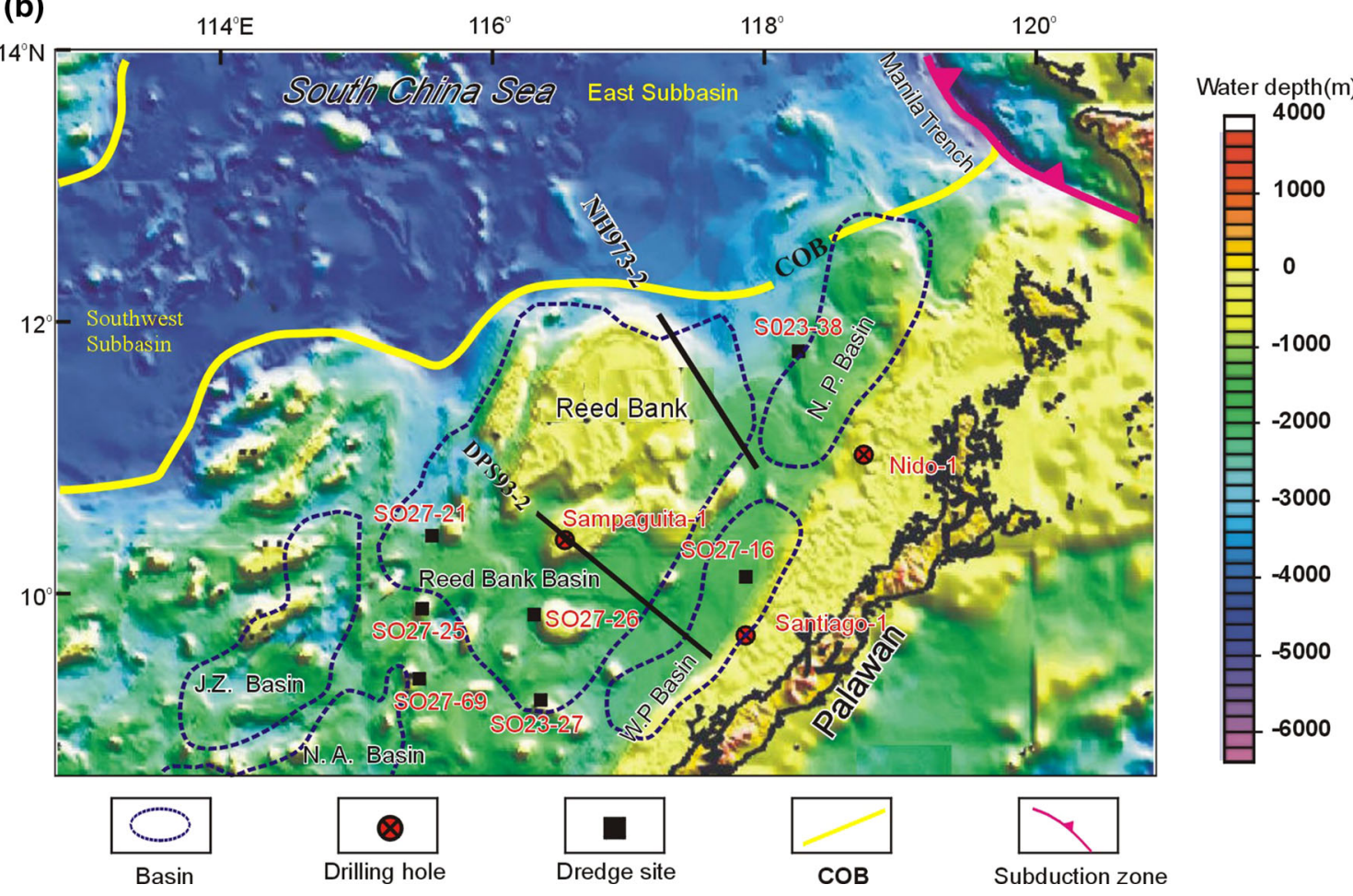


4Fig. 1 a Tectonic structures and bathymetry of the South China Sea and adjacent regions. Three isobaths shown on the map are 100 , 1,000, and 3,000 m, respectively. The block open box shows the study area. PRM Basin Pearl River Mouth Basin, QDN Basin Qiongdongnan Basin; b morphological features and major tectonic units in the southeastern margin of the South China Sea. Black lines are the multichannel seismic profiles used in this study. Continent-ocean boundary (COB) is shown according to Franke et al. (2013). Dredge sites (numbers) are reported from Kudrass et al. (1986). Well locations are reported from Taylor and Hayes (1983) and Schlueter et al. (1996)

regional time-space distributions, control processes and geologic evolution model (Wilson et al. 2000; $\mathrm{Xu}$ et al. 2002; Madden and Wilson 2013).

The top of the shallow water carbonate deposition in the South China Sea continental margin is characterized by a strong and continuous seismic reflector in the seismic records. It also forms a regional unconformity truncating the sequence beneath (Ding et al. 2013; Franke et al. 2013). Most authors concluded that the carbonate platforms and patch reefs generally developed during the Early Miocene and their formation migrated from $\mathrm{E}$ to $\mathrm{W}$ and from $\mathrm{S}$ to $\mathrm{N}$ (Wu et al. 2008; Ma et al. 2011; Xie et al. 2011; Franke et al. 2013).

However, efforts still need to be made on the southeastern margin of the South China Sea, or the Reed Bank area, where we can find the oldest carbonate platforms here formed as early as the Late Oligocene (Kudrass et al. 1986). This region has been also confirmed as the site of important deep water oil and gas reservoirs (Sales et al. 1997; Zampetti et al. 2004). In this study, we present two high-resolution multi-channel seismic profiles across the Reed Bank area of South China Sea to document the seismic characteristics of carbonate platform and different types of carbonates, the interplay between tectonics, sea level change and depositional rates resulting in a complex platform geometry and the geologic evolution models. The main goal of this work was to present an overview of carbonate platform development since the Late Oligocene in the Reed Bank area, South China Sea.

\section{Regional geological setting}

The study area lies in the north-eastern part of the Dangerous Grounds, between the oceanic basin of the South China Sea and the Palawan (Fig. 1a). The water depth ranges from tens of meters up to $2,000 \mathrm{~m}$. This area is characterized by a fragment of continental lithosphere (the Reed Bank), by the surrounding Reed Bank Basin, West Palawan Basin and North Palawan Basin (Fig. 1b). The submarine topography of this area is characterized by different morphologies, such as coral reefs, seamounts, sea knolls, canyons, scattered throughout this area. It is generally accepted that the Reed Bank area, as the Dangerous Grounds, constitutes stretched crust of continental origin (Holloway 1982; Taylor and Hayes 1983; Yan and Liu 2004; Cullen et al. 2010; Ding et al. 2013).

The entire Dangerous Grounds area experienced strong rifting during the Cenozoic which resulted in abundant normal faulting and the formation of wide half-grabens. Unlike the rifted basins at the northern continental margin of the South China Sea, the horst and graben structures in the Dangerous Grounds are bathymetrically expressed (Yan and Liu 2004; Ding et al. 2013). Tilted horst blocks form topographic highs with presumably reefs on top (Hutchison and Vijayan 2010). Most extensional structures, including graben and horst, are connected along a lowangle detachment system (Ding et al. 2013). This detachment system may have developed in the final stage of rifting as indicated by a decollement system close to the continental-oceanic transition area (Franke et al. 2013). Wide-angle refraction/reflection results proved the Dangerous Grounds reflect a magma-poor rift system at the initial stage of mantle unroofing (Ruan et al. 2011; Qiu et al. 2011).

The nature and composition of the acoustic basement, however, is unclear. A Paleozoic and/or Mesozoic basement may be inferred based on dredge samples and limited wells. The sampled rocks show a close affinity to those of Southeast Asia, suggesting that the Reed Bank area once was a part of the South China Continent (Hutchison 2004; Kudrass et al. 1986; Yan and Liu 2004). After a Cretaceous to Late Paleogene period of rifting, which led to the formation of numerous NE-SW trending half-grabens, the continental fragments were finally separated from the South China continent by seafloor spreading (Taylor and Hayes 1983, Taylor and Hayes 1983; Briais et al. 1993).

The opening scenario of the South China Sea, proposed by Taylor and Hayes (1983) and Briais et al. (1993), has been generally accepted, i.e. seafloor spreading occurring from 30 to $16 \mathrm{Ma}$ (magnetic anomaly 11-5C). The spreading history was complicated by two southwards trending ridge jumps and by a south-westwards ridge propagation at about $23.8 \mathrm{Ma}$, after which the break-up tectonic phase occurred in the Southwestern sub-basin. New high resolution sea floor survey of magnetic anomalies has confirmed the spreading age, ranging in age between 31.7 to 16.9 Ma (Lin et al. 2013).

During the Paleogene, the Reed Bank was still attached to the South China Continent and was likely joined with Zhongsha Islands (Macclesfield Bank). Following seafloor spreading in the Middle Oligocene, Reed Bank moved southwards, together with the Dangerous Grounds (Taylor and Hayes 1980; Briais et al. 1993; Sun et al. 2009), and finally collided with Palawan and Borneo continents during the Middle Miocene (Hutchison et al. 2000; Clift et al. 


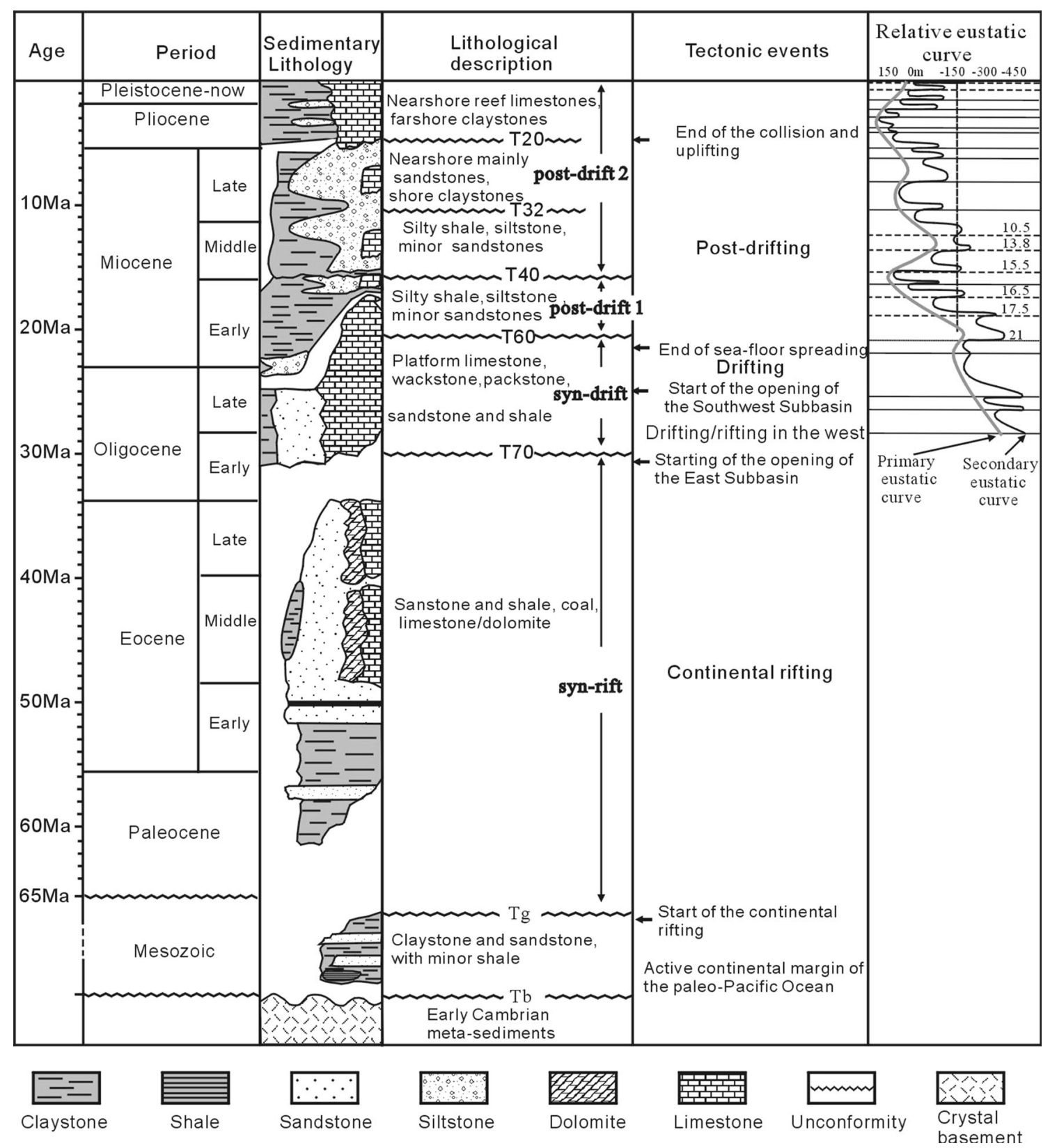

Fig. 2 Seismic stratigraphy, lithology, major tectonic events and eustatic sea level curve of the study area. The relative sea level eustatic curve is reported from Pang et al. (2007)

2008; Cullen et al. 2010; Hutchison 2010). This collision, together with the Palawan/Mindoro-Central Philippines collision event (Yumul et al. 2003), is considered as originating at the end of the seafloor spreading in the South China Sea.

\section{Datasets and methods}

This study bases on two newly-acquired multi-channel seismic lines. The NH973-2 seismic line was recorded during the "Project 973 Cruise" in 2009 with the Chinese R/V "Tanbao" (Fig. 1b). It crosses the north-eastern part of the Reed Bank and part of the Reed Bank Basin. The DPS93-2 seismic line was recorded by the Federal Institute for Geosciences and Natural Resources (BGR) and runs through the south-western sector of the Reed Bank, part of the Reed Bank Basin, and part of the West Palawan Basin (Fig. 1b).

Published dredging data (Kudrass et al. 1986) and data from limited wells (Sampaguita-1 well in Reed Bank, Nido-1 well and Santiago-1 well offshore Palawan) were 

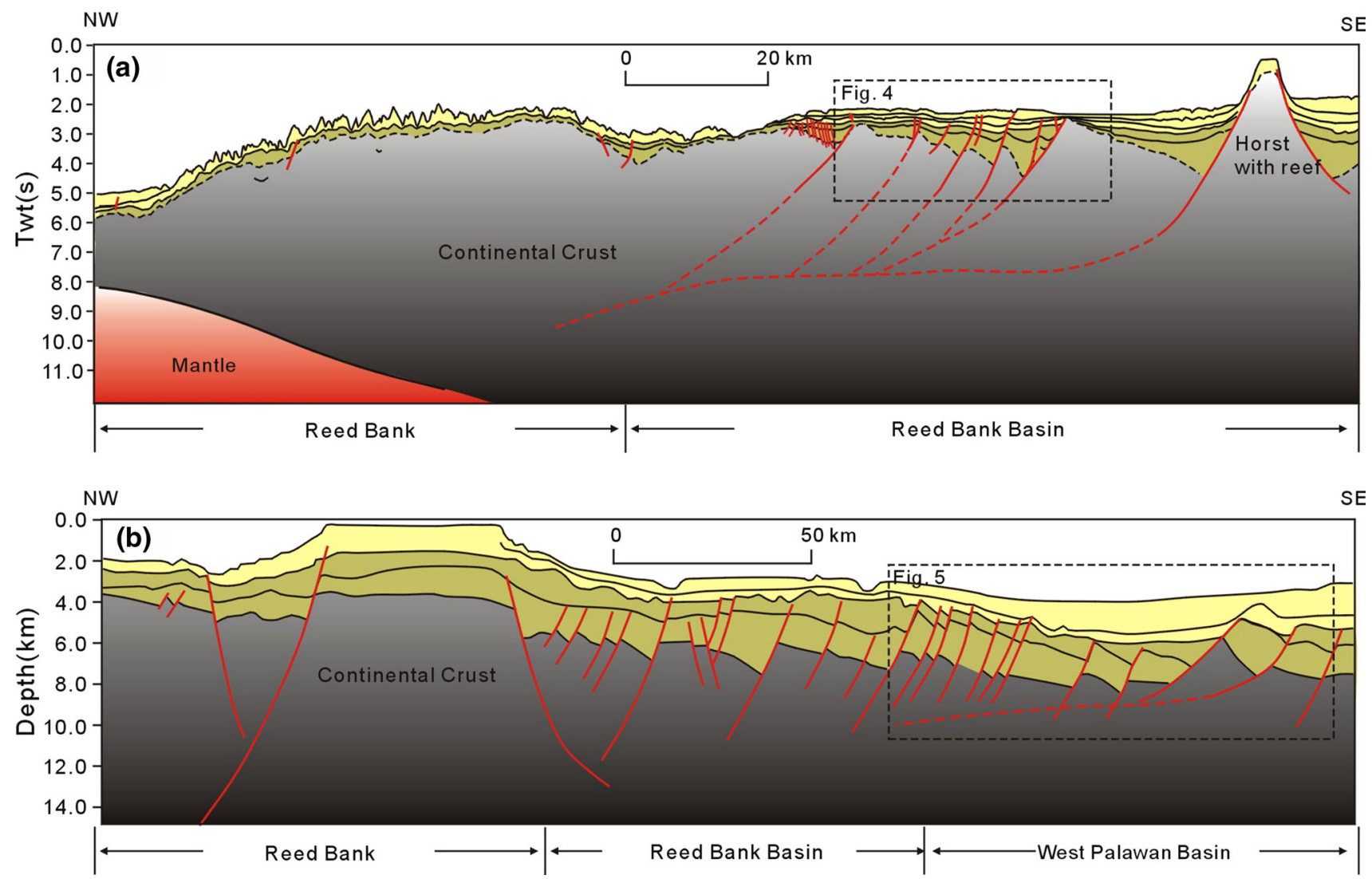

Fig. 3 Geological interpretations of multi-channel seismic profile NH973-2 (top) and DPS93-2 (down, modified from Franke et al. 2013). The areas where tectonic subsidence have been calculated are indicated in dashed square

used to calibrate the geologic interpretation of seismic sequences carried out on seismic profiles against regional litho-stratigraphic units (see Fig. $1 \mathrm{~b}$ for locations). In addition, we incorporated published stratigraphic schemes from the study area (Hinz and Schlueter 1985; Hinz et al. 1989; Clift et al. 2008; Franke et al. 2008, 2013; Cullen et al. 2010; Hutchison and Vijayan 2010; Yao et al. 2012; Ding et al. 2011). In the Fig. 2 the details of seismic stratigraphy, lithology, and major tectonic events have been reported. Our approach in the identification of regional unconformities is based on seismic characteristics, including reflection frequency, amplitude and continuity, and reflection termination (onlap, downlap and erosional truncation) (Figs. 3, 4a, b).

An approach to the modeling of unloaded tectonic subsidence analysis was chosen to gain more insights to the interplay of tectonics, sedimentation, and subsidence. The Temis 2D software (ESSCA Company) has been used for the measurement of tectonic subsidence from seismic profiles. A time to depth conversion has been carried out in order to construct the cross sections used for subsidence analysis. The time-velocity statics over the Reed Bank area for subsidence analysis has been adopted according to Yan and Liu (2004). A set of artificial wells has been constructed along our two seismic profiles in order to recover the tectonic component of subsidence in the study area and the backstripping technique (Steckler and Watts 1978) has been used. The statistics of lithologic parameters of each layer are list in Table 1.

Water-loaded tectonic subsidence has been determined from the stratigraphic records adopting Airy isostatic correction in order to correct for the effect of sediment loading. The corrections for compaction of sediments have been made by using porosity-depth relationships based on the observed lithologies (Sclater and Christie 1980). The lithology of each sequence and the palaeo-water depth information during the backstripping process have been referred to wells located in this area (such as the Sampaguita-1 well) and previous studies (Hinz and Schlueter 1985; Hazebroek and Tan 1993; Franke et al. 2008; Cullen et al. 2010; Yao et al. 2012; Ding et al. 2013).

The water depth plays an important role in backstripping and could make the subsidence history accurately. Several wells with biostratigraphic data in the Reed Bank area and offshore Palawan (e.g., wells Sampaguita-1, Santiago-a, Nido-1; see Fig. 1 for their locations) have been used to 
(a)

\begin{tabular}{|c|c|c|c|c|c|}
\hline Unit and age & $\begin{array}{c}\text { Internal reflector } \\
\text { pattern }\end{array}$ & Frequency & Intensity & Continuity & \\
\hline $\begin{array}{c}\text { Post-drift } 2 \\
\text { (T40-present, } 15.3 \\
\text { Ma-present) }\end{array}$ & $\begin{array}{l}\text { Parallel, locally } \\
\text { wavy }\end{array}$ & Uniform & $\begin{array}{l}\text { Moderate-high } \\
\text {, locally } \\
\text { transparent }\end{array}$ & high & 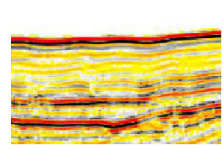 \\
\hline $\begin{array}{c}\text { Post-drift } 1 \\
\text { (T60-T40, } 20-15.3 \\
\text { Ma) }\end{array}$ & Parallel-subparallel & $\begin{array}{l}\text { Uniform, } \\
\text { locally } \\
\text { variable }\end{array}$ & $\begin{array}{l}\text { Moderate, } \\
\text { locally } \\
\text { transparent }\end{array}$ & $\begin{array}{l}\text { Intermediate- } \\
\text { high }\end{array}$ & 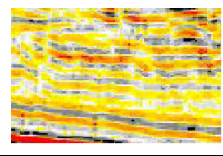 \\
\hline $\begin{array}{l}\text { Syn-drift (T70-T60, } \\
32 \mathrm{Ma}-17 \mathrm{Ma})\end{array}$ & $\begin{array}{c}\text { Subparallel, locally } \\
\text { chaotic }\end{array}$ & $\begin{array}{l}\text { Slightly } \\
\text { variable }\end{array}$ & $\begin{array}{l}\text { Moderate- } \\
\text { high }\end{array}$ & $\begin{array}{l}\text { Intermediate- } \\
\text { high }\end{array}$ & 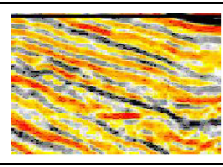 \\
\hline $\begin{array}{l}\text { Syn-rift (Tg-T70, } \\
65 \text { Ма- } 32 \mathrm{Ma})\end{array}$ & $\begin{array}{c}\text { Chaotic, locally } \\
\text { subparallel }\end{array}$ & variable & High-variable & Low & wowitus \\
\hline Pre-rift (>65 Ma) & Parallel-subparallel & $\begin{array}{l}\text { Slightly } \\
\text { variable }\end{array}$ & Low-moderate & $\begin{array}{l}\text { High- } \\
\text { intermediate }\end{array}$ & 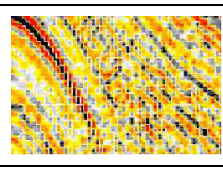 \\
\hline
\end{tabular}

(b)

\begin{tabular}{|c|c|c|}
\hline $\begin{array}{l}\text { Sequence } \\
\text { boundary and age }\end{array}$ & Reflection pattern & \\
\hline $\begin{array}{c}\mathrm{T} 32 \\
(\sim 10.5 \mathrm{Ma})\end{array}$ & $\begin{array}{c}\text { Nearly parallel to seafloor, moderate } \\
\text { amplitude, moderate continuous, } \\
\text { locally truncation under the } \\
\text { boundary }\end{array}$ & 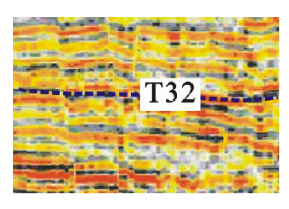 \\
\hline $\begin{array}{c}\mathrm{T} 40 \\
(15.3 \mathrm{Ma})\end{array}$ & $\begin{array}{l}\text { High amplitude with good } \\
\text { continuity, truncation below }\end{array}$ & 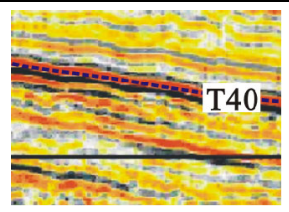 \\
\hline $\begin{array}{c}\text { T60 } \\
(20 \mathrm{Ma})\end{array}$ & $\begin{array}{l}\text { Strong-very strong amplitude with } \\
\text { good continuous, truncation below }\end{array}$ & 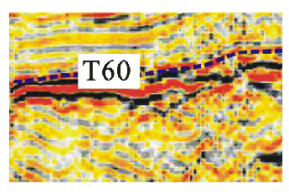 \\
\hline $\begin{array}{c}\mathrm{T} 70 \\
(32 \mathrm{Ma})\end{array}$ & $\begin{array}{c}\text { Moderate-strong amplitude, } \\
\text { patchy-continuous, truncation below }\end{array}$ & 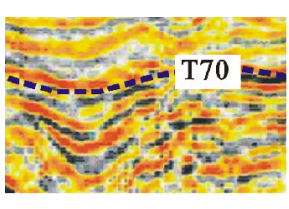 \\
\hline $\begin{array}{c}\mathrm{Tg} \\
\text { (Basement of } \\
\text { Cenozoic) }\end{array}$ & Strong amplitude, continuous & 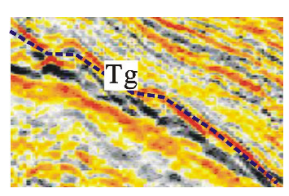 \\
\hline
\end{tabular}


4Fig. 4 a Seismic facies and sequences with tentative ages in the studies area; b reflection pattern with tentative ages of the main unconformities identified in the study area

constrain the palaeo-bathymetries in the study area. Several scientists have made a detailed biostratigraphic analysis to the above mentioned palaeo-bathymetries (Kudrass et al. 1986; Schlueter et al. 1996; Franke et al. 2011; Yao et al. 2012; Steuer et al. 2013). The sediments older than Eocene show lacustrine and delta facies, composed of sandstones and shales, with coal. So the water depth in the initial rifting stage ( $\sim 65 \mathrm{Ma}$ ) is assumed to be zero. Between the Paleocene and the Middle Oligocene $(\sim 65-32 \mathrm{Ma})$ the sediments changed from abyssal facies characterized by gray and green-brown calcareous shales, to neritic facies, characterized by interbedded sandstones and mudstones, showing an overall decrease of water depth (from 500 to $100 \mathrm{~m}$ ). During the drifting stage (32-17 Ma) a well developed carbonate platform indicates a palaeo-bathymetry of shallow water (less than $50 \mathrm{~m}$ ). On the other side, after 15.3 Ma the water depth rapidly increased, and a deep water portion is estimated (where some part of the present-day bathymetry is greater than 3,500 m). Although the eustatic sea-level fluctuation has less influence on backstripping, if compared to the variations of palaeo-bathymetry, the relative sea level change in Cenozoic (Pang et al. 2007) has been incorporated in backstripping in order to make the subsidence study integrity.

\section{Results}

Seismic stratigraphy

Seven seismic units have been identified in the Reed Bank area, featuring particular reflection patterns and internal structure (Fig. 4a). The units are separated by six regional unconformities (Figs. 2, 4b). The pre-rift, syn-rift (TgT70), drift (T70-T60) and post-drift (T60-recent) tectonostratigraphic units correspond to distinct and different environments and tectonic phases. The post-drift unit was further subdivided into four sub-units.
$\mathrm{Tg}$, the deepest traceable reflector in the seismic sections, represents the top of the Mesozoic pre-rift unit and is characterized by moderate- to high-amplitude, continuous reflections, locally diffractive hyperbolas, indicating a strong erosion. This reflection is typically well defined and corresponds either to the top of tilted blocks or it forms the base of the wedge-shaped syn-rift sedimentary infill (Figs. 5, 6). An erosional truncation resulting in an angular unconformity occasionally occurs beneath that horizon. The pre-rift unit is composed of sandstones, siltstones with plant debris and dark-green claystones with Upper Triassic to Lower Jurassic shells deposited in fluvial or coastal to shallow marine environment (Schlueter et al. 1996). In addition, there are metamorphic rocks, such as biotitemuscovite-feldspar-quartz migmatites or gamet-micaschists (Taylor and Hayes 1983; Kudrass et al. 1986).

A syn-rift unit (Tg-T70, 65-32 Ma) was defined mainly on basis of the wedge-shape of this succession, meaning that it is syntectonic and deposited during the extensional rift deformation. The unit, sealed by unconformity, is characterized by chaotic, locally subparallel and discontinuous to moderate continuous reflectors with low frequency (Fig. 4a), indicating clastic sediments infilling half-grabens during the rifting phase (Fig. 2). In both profiles T70 shows moderate- to high-amplitude and continuous- to discontinuous-reflectors. Locally, it is truncated underneath and onlap at its top (Fig. 4b). We propose that this boundary represents the break-up unconformity (BU) of the East sub-basin of the South China Sea, having an age of about $32 \mathrm{Ma}$ in the eastern sector of the SCS.

Similar to the syn-rift unit, the drift unit (T70-T60, 32-17 Ma) is confined into the half-grabens genetically related to the rifting phase. It is generally thinner than the syn-rift unit (Tg-T70, $\sim 65-32 \mathrm{Ma}$ ) and is characterized by sub-parallel reflectors of high to intermediate continuity and moderate amplitude (Fig. 4a). This unit was deposited during the drifting period of the South China Sea and represented by carbonate deposits. T60 marks not only another major regional unconformity, separating the rifting infill from the draping deposits in the Dangerous Grounds area, but also forming the top of a carbonate sequence

Table 1 Statistics of lithology, lithologic parameters and paleo-water depth of each sediment unit

\begin{tabular}{|c|c|c|c|c|c|c|c|}
\hline \multirow[t]{2}{*}{ Units } & \multicolumn{3}{|c|}{ Lithology (\%) } & \multicolumn{3}{|l|}{ Parameters } & \multirow[t]{2}{*}{ Paleo-water depth $(\mathrm{m})$} \\
\hline & Mudstone & Sandstone & Carbonate & rho_G $\left(\mathrm{kg} / \mathrm{m}^{3}\right)$ & SurPor & $\mathrm{CC}(/ \mathrm{m})$ & \\
\hline T20-recent & 48. 4 & 28.5 & 23.1 & 2,698 & 0.61 & 0.00049 & 2,500 \\
\hline T32-T20 & 36.6 & 25.9 & 37.5 & 2,698 & 0.62 & 0.00052 & 1,500 \\
\hline T40-T32 & 29.9 & 9.6 & 60.5 & 2,707 & 0.66 & 0.00061 & 750 \\
\hline Т60-T40 & 18.2 & 18.8 & 63.0 & 2,701 & 0.65 & 0.00059 & 350 \\
\hline T70-T60 & 18.2 & 13.3 & 68.5 & 2,704 & 0.66 & 0.00062 & 40 \\
\hline $\mathrm{Tg}-\mathrm{T} 70$ & 62.6 & 34.6 & 2.8 & 2,695 & 0.58 & 0.00043 & 300 \\
\hline
\end{tabular}



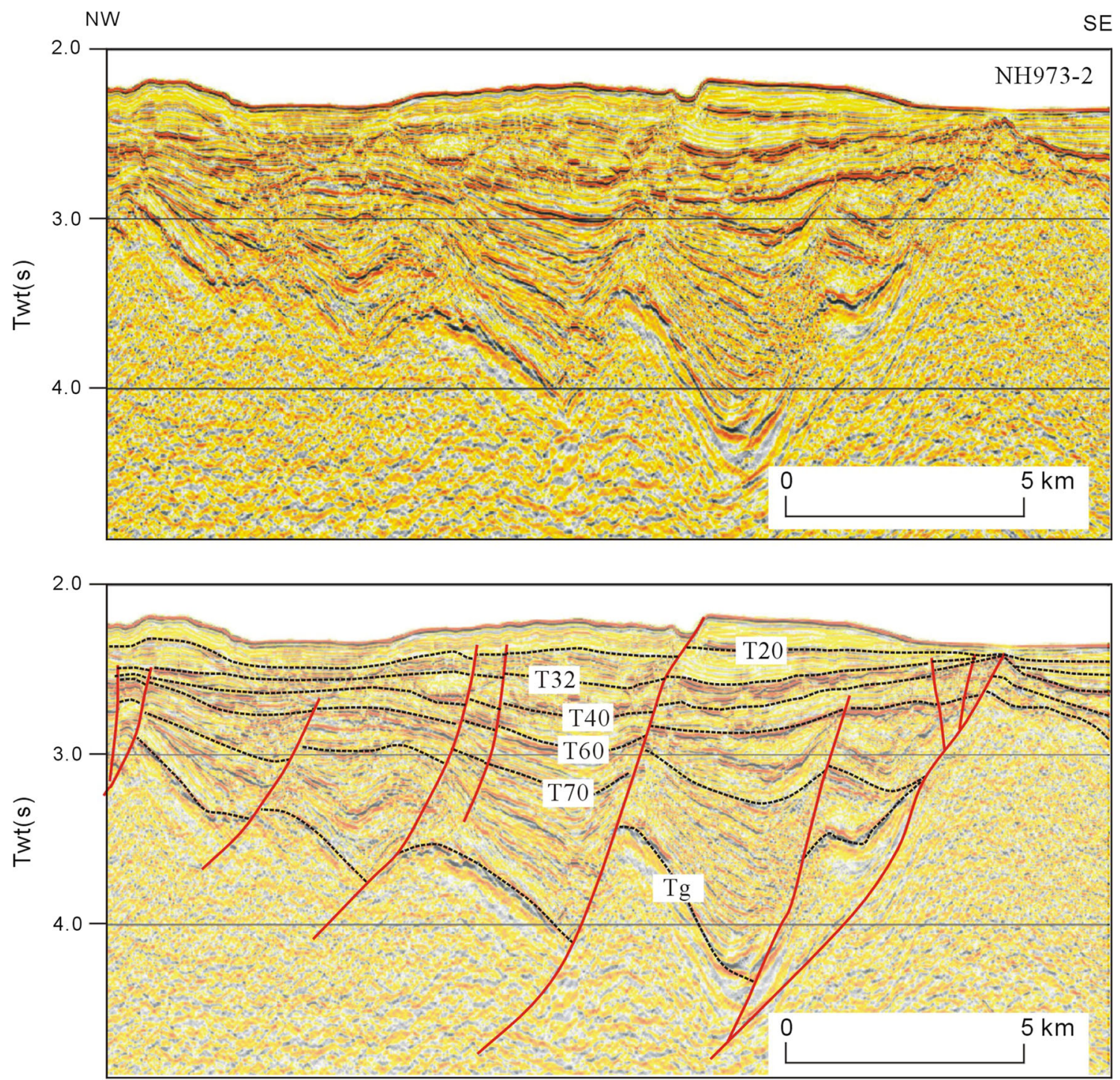

syn-rift (Tg -T70, 65 Ma- 32 Ma); syn-drift (T70-T60, $32 \mathrm{Ma}-17 \mathrm{Ma})$;

post-drift 1 (T60-T40, $17 \mathrm{Ma}-15.3 \mathrm{Ma}$ ); post-drift 2(T40-seafloor, 15.3 Ma - present)

Fig. 5 Seismic example section (top) and geological interpretation (down), showing the main interpreted horizons and sequences. The succession which is controlled by normal faults (syn-rift and drift units, $\mathrm{Tg}-\mathrm{T} 60$ ) is wedge shaped with a distinct angular unconformity

(Fig. 4b). An age of $20 \mathrm{Ma}$ is proposed for this unconformity, whose details will be discussed in the following paragraphs.

The post-drifting unit (T60-seafloor, $17 \mathrm{Ma}-$ Recent) is characterized by draping strata distinguished from continuous, sub-parallel to parallel reflectors. The ODP Site 1143 penetrated the Upper Miocene to present-day post-drift strata, recovering $500 \mathrm{~m}$ of claystones, sandstones and highly calcareous nannofossil oozes, with foraminifera in alluvial to open marine environments (ODP Shipboard Scientific Party 2000). The Late Miocene sequences have been drilled by wells and crop out onshore in the Philippine islands (Palawan) with similar
(T60) on top. The latter may represent the top of carbonate platforms. The unit below shows base parallel bedding and thus is interpreted as pre-rift sedimentary sequence (see Fig. 3 for location)

lithologies (Yumul et al. 2003; Steuer et al. 2013). Several seismic unconformities have been identified as T40, T32 and T20. T40 may be an equivalent of the top of the Pagasa Formation that is known from offshore Palawan, and is interpreted to separate the generally deep marine clastic sedimentation during a pre-early Middle Miocene phase from younger clastic shelf/slope deposits (Figs. 2, 4b). We set an age of 15.3 Ma to T40 (Franke et al. 2008, 2013). T32 and T20 are two other unconformities in the post-drift deposits. From a similar reflection pattern across ODP Site 1143 on the Dangerous Grounds (ODP Shipboard Scientific Party 2000), we infer ages of 10.5 and $5.5 \mathrm{Ma}$, respectively. 

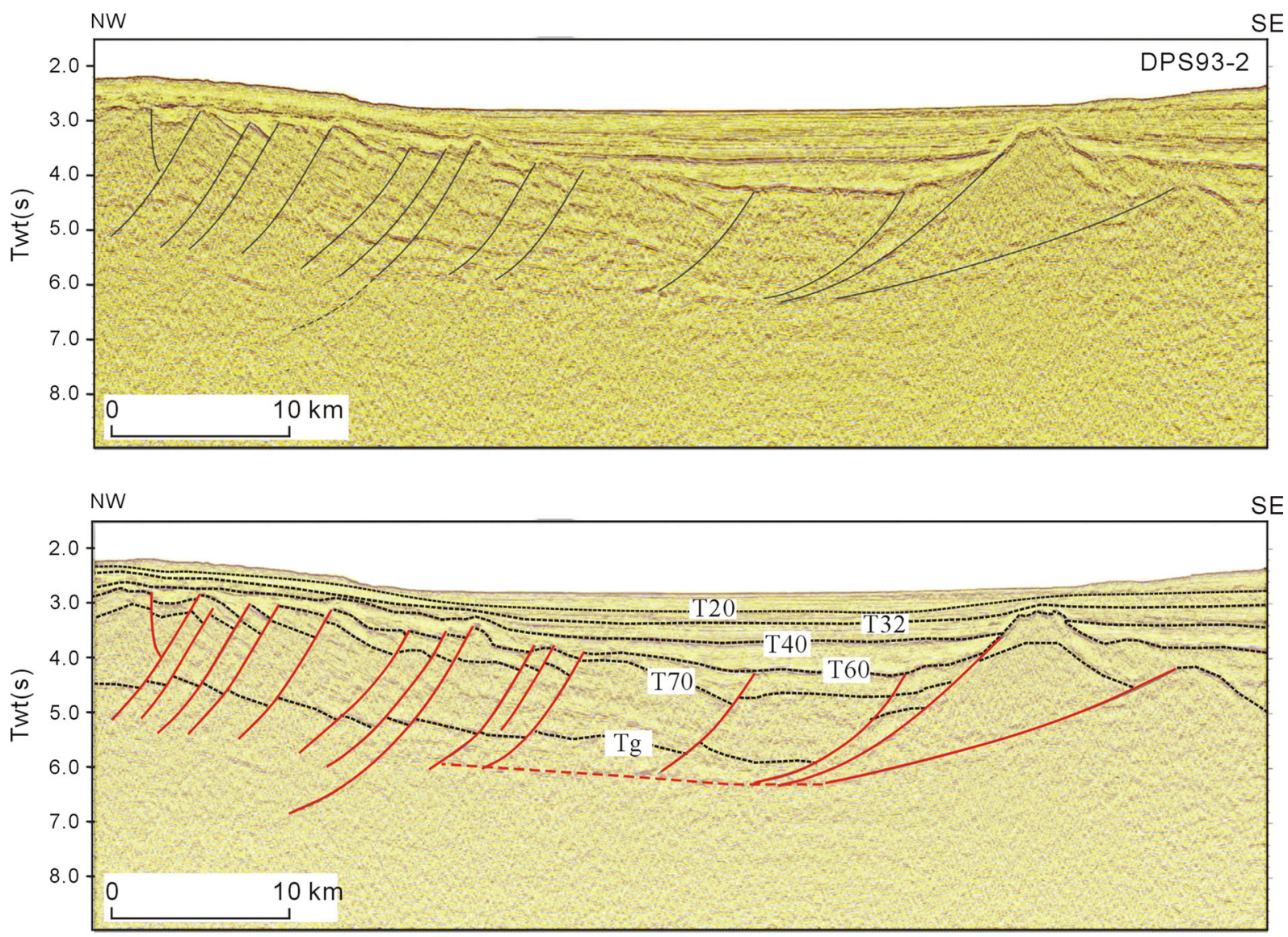

syn-rift (Tg -T70, $65 \mathrm{Ma}-32 \mathrm{Ma}) ; \quad$ syn-drift (T70-T60, $32 \mathrm{Ma}-17 \mathrm{Ma}$ ); post-drift 1 (T60-T40, $17 \mathrm{Ma}-15.3 \mathrm{Ma}$ ); post-drift 2(T40-seafloor, $15.3 \mathrm{Ma}$ - present)

Fig. 6 Seismic example section (top) and geological interpretation (down). Modified from Franke et al. 2013. The succession which is controlled by normal faults (syn-rift and drift units, Tg-T60) is wedge shaped with a distinct angular unconformity (T60) on top. Listric faults bounding a strongly rotated crustal fault block with a reef on

Seismic characteristics and lithology of carbonate platforms and reefs

Shallow water carbonates and reefs have been reported in the southern margin of the South China Sea, including the Dangerous Grounds, the Reed Bank, and the north-western Palawan offshore (Schlueter et al. 1996; Yao et al. 2012; Steuer et al. 2013). In the seismic profiles this stratigraphic sequence, coeval with the drifting episode (32-17 Ma), is the most prominent one. Carbonates, including grainstones, wackstones and packstones with Late Oligocene to Early Miocene foraminifera, have been sampled at 23 sites to the south and to the south-west of Reed Bank (main sites are listed in Table 2). The carbonates were deposited in lagoon or shallow open marine environment (Fig. 2). The tectonostratigraphic unit has been interpreted as a carbonate platform unit based on the abundant occurrence of carbonates in the dredges, on reflection pattern, and on occurrence of reef deposits at the top of this unit. top are soling out in the detachment fault. Several steep secondary faults interact at high angles with this detachment fault, indicating renewed extension after the formation of carbonate platforms (see Fig. 3 for location)

The T60 unconformity is located at the top of the carbonate platform. This unconformity is striking in the seismic records with strong and continuous reflectors, truncating the underlying sequence (Figs. $4 b, 5,6$ ). The seismic reflectors inside the platform unit are characterized by low amplitude. Previous study proved that this unconformity is widely established in the southern margin of the South China Sea, extending from the Dangerous Grounds to beneath the north-western Borneo Trough (Franke et al. 2011; Ding et al. 2013). The age of T60, marking the end of carbonate platform growth, is uncertain since the limestone deposition may have ended at different times throughout the area, continuing in some areas as reef buildups almost up to the Middle Miocene, or elsewhere is terminated at the end of the Late Oligocene (offshore NW Palawan, Williams 1997) or in the Early Miocene (Dangerous Grounds; Schlueter et al. 1996; Ding et al. 2013). Hutchison and Vijayan (2010) stated this unconformity is Early Miocene in age, dating back it with a Sr isotopic age 
Table 2 Lithology and depositional environments of carbonate rocks (modified from Kudrass et al. 1986)

\begin{tabular}{|c|c|c|c|}
\hline Position & Lithology & Age & Deposition environment \\
\hline $\mathrm{SO} 23-27$ & Loosely packed, red algae-rich grainstone, intraclastic wackestone & L. Oligocene-E. Miocene & $\begin{array}{l}\text { Shallow-deep open marine, } \\
\text { lagoon }\end{array}$ \\
\hline $\mathrm{SO} 23-38$ & $\begin{array}{l}\text { Porous, red algae-Cycloclypeus-bearing wackestone, bioclastic } \\
\text { wackestone }\end{array}$ & $\begin{array}{l}\text { L. Oligocene-early M. } \\
\text { Miocene }\end{array}$ & Shallow-deep open marine \\
\hline $\mathrm{SO} 27-16$ & Moldic wackestone with veins, intraclastic packstone & L. Oligocene-M. Miocene & Shallow-deep open marine \\
\hline $\mathrm{SO} 27-21$ & Layered, Qz-bearing, red algae rich packstone & L. Oligocene-E. Miocene & Shallow open marine \\
\hline SO27-25 & Red algae-rich wackestone, intraclastic, red algae-rich packstone & L. Oligocene-E. Miocene & Shallow open marine \\
\hline $\mathrm{SO} 27-26$ & Porous, red algae-rich packstone and fp-wackestone & L. Oligocene-E. Miocene & Deep open marine \\
\hline $\mathrm{SO} 27-69$ & Orbitoid-rich packstone, fp-bearing wackestone & $\begin{array}{l}\text { L. Eocene-early M. } \\
\text { Miocene }\end{array}$ & $\begin{array}{l}\text { Shallow-deep open marine, } \\
\text { bathyal }\end{array}$ \\
\hline
\end{tabular}

of 18.5-19.0 Ma. By analyzing the sedimentary rate and the overlying strata with several wells penetrating the carbonate platforms offshore Palawan, Steuer et al. (2013) gave ages for the end of carbonate platform deposition from latest Oligocene to earliest Miocene, at 18-20 Ma Consequently, T60 is a diachronous surface because of progressive uplift and westward tilting of the Sabah Orogeny (Levell 1987). This unconformity forms an angular unconformity and represents a widespread erosional phase, which is related with the collision between the Reed Bank and Palawan in Middle Miocene ( 16 Ma) (Hutchison and Vijayan 2010). Given an erosive hiatus of about 3-4 m.y., an age of $20 \mathrm{Ma}$ for this unconformity is suggested in the Reed Bank area. This timing rather coincides well with the end of the oceanic spreading in the South China Sea at nearly $17 \mathrm{Ma}$. In the south-western Reed Bank area, this unconformity is also cut by normal faults, indicating a younger extensional phase (Fig. 6).

Several patch reefs have been identified between the Reed Bank and the Palawan offshore, which have been mapped in our seismic profiles (Fig. 7a). These reef buildups show a horse-shoe shape and mainly developed upon structural highs. These horse-shoe reefs have been identified on the seismic profiles by high amplitude, mounded reflectors at their tops, chaotic reflections within, and high-amplitude, discontinuous reflectors in the adjacent basin (Fig. 7a). The overlying deposits onlap onto the tops of horse-shoe reefs, forming draping structures. The age of the end of reef deposition is different in several areas of the Reed Bank area. In some areas the reefs just ended their development clearly before the T40 unconformity (15.3 Ma; Fig. 5). The coverage by the Middle Miocene deposition indicates a drowning of this reef due to combined effects of strong subsidence and sea-level rise. In other areas the reef continued to grow after the T40 unconformity (15.3 Ma; Fig. 6). In some places these reefs reach up to the present sea floor but are now in water depths greater than $500 \mathrm{~m}$.
The Reed Bank is considered as a rigid continental block, which has experienced a little tectonic deformation during the Cenozoic (Sun et al. 2009). The only sedimentary succession that clearly continues across the whole structure range in age from the T60 unit to recent times. The carbonate reefs are dominant topographies in the Reed Bank, forming the rugged morphology of the sea floor. Several wells have been drilled in this area, among which the Sampagita-1 well has the greatest drilling depth $(4,125 \mathrm{~m})$ and provided the most complete stratigraphic sequence (Taylor and Hayes 1980, 1983).

Besides $674 \mathrm{~m}$ Mesozoic strata (Early Cretaceous siltstones, shales mixed with coal, sandstones and aggregates) and 1,287 $\mathrm{m}$ Paleogene strata (Paleocene to Lower Oligocene sandstones, mudstones and shales), about 2,164 m white-light yellow neritic to littoral facies carbonate rocks was discovered, which changes from limestone and dolomitized limestone in the upper part to dolomite at the bottom. In seismic profiles these carbonate buildups are characterized by high amplitude, mounded reflectors at their tops, and parallel or sub-parallel bedded, middle to low amplitude, and continuous reflector within (Fig. 7b). This carbonate sequence unconformably covers the underlying sequence. This unconformity is characterized in our seismic profile by a high amplitude and continuous seismic reflectors (Figs. 5, 6).

\section{Cenozoic tectonic subsidence}

The calculation of the tectonic subsidence in the Reed Bank area is critical to our understanding of the geodynamics of the Cenozoic extension in the South China Sea continental margin. It has conditioned our ability to accurately assess the sedimentary process. A time to depth conversion was attempted before the tectonic subsidence calculation (Fig. 8). An overview of the backstripped tectonic subsidence curves for all the analyzed artificial wells is shown in Fig. 9. 

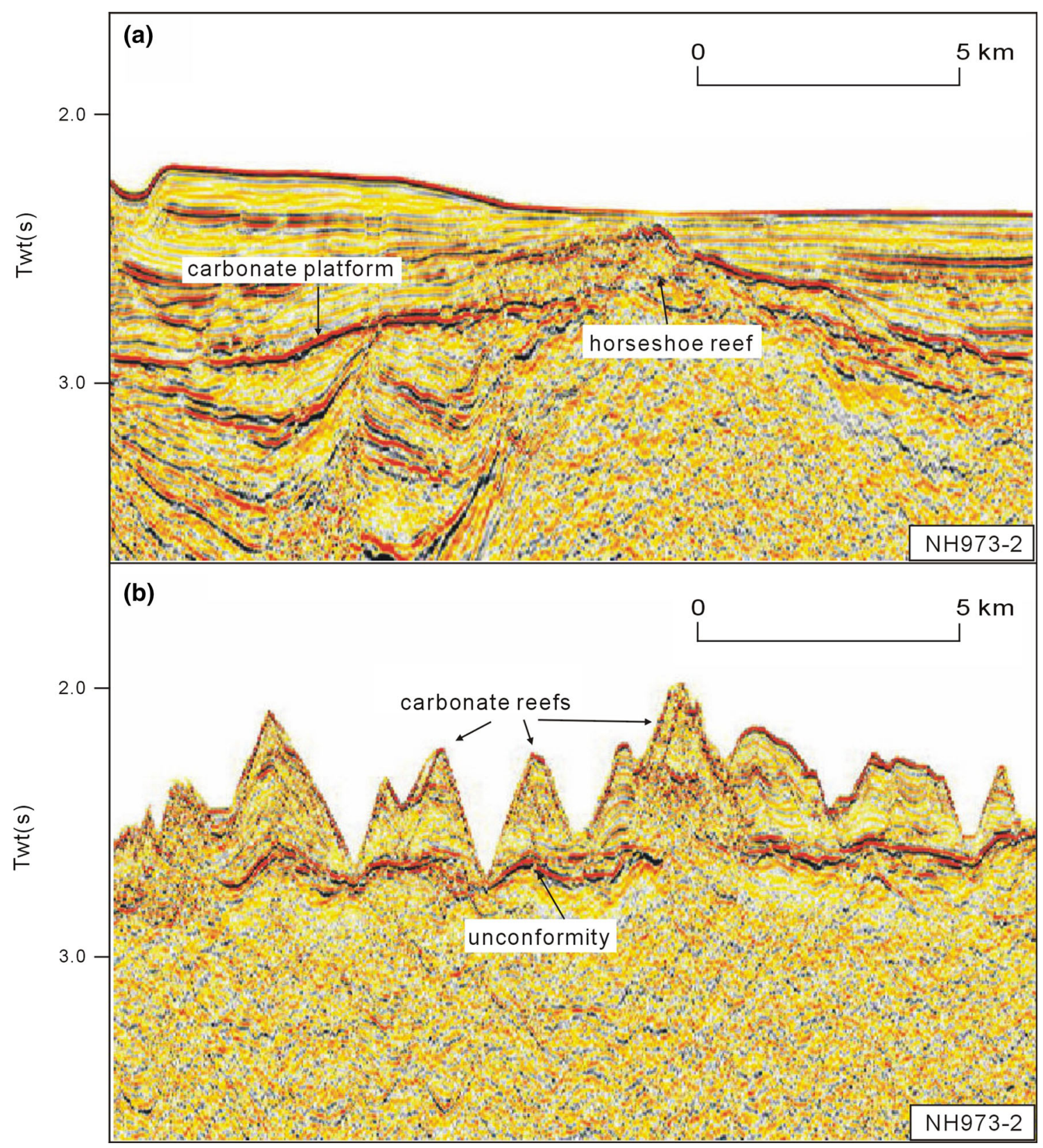

Fig. 7 Typical seismic characteristics of carbonate platform and horseshoe reef (up) and reef buildups (down)

These curves clearly show different subsidence rates, corresponding with syn-rift, drift and post-drift stages. The initial subsidence during the active extensional phase has been recognized from the late Cretaceous (Tg, $\sim 65 \mathrm{Ma}$ ) to the late Oligocene (T70, 32 Ma). Previous studies have suggested episodic extension in the continental margin of the South China Sea with combined influences of the eastward retreat of the West Pacific subduction zone and the collision and northward impinging of the India Block to the Tibet Block (Tapponier et al. 1986; Zhou et al. 1995; Clift et al. 2008; Cullen et al. 2010). In our study, a classification of extensional episodes has not been carried out and the tectonic subsidence during this stage has been simplified. In most cases, especially in the deep part of the basin, the sag is featured with three episodes of rapid subsidence intermitted with slower subsidence (Fig. 9). The first period of rapid subsidence occurred during the rifting stage (T70-T60, 65-32 Ma), which has been followed by a reduced subsidence rate after $32 \mathrm{Ma}$. The slow subsidence lasted during the drifting stage for more than 10 m.y. An accelerated subsidence occurred after the end of the sea floor spreading at $17 \mathrm{Ma}$ and continued since to $15 \mathrm{Ma}$ (T20), indicating the quick thermal subsidence during the post-drifting stage and a sharp change of 
sedimentary environment. Following a stage of relative smooth curves, the tectonic subsidence increased again after $\sim 5.5 \mathrm{Ma}$, until to the present (Fig. 9). This quick subsidence since the Pliocene is common in the continental margin of the South China Sea (Clift and Lin 2001; Zhao et al. 2013; Chen 2014), detailed analysis about that is ignored in this paper since it's beyond our topic.

\section{Discussion}

Controlling factors on the carbonate development: tectonics subsidence versus sea level change

The dominant role on the development of the carbonate platform and reef deposits is played by water depth, which is a response of the interplay of relative sea level changes and tectonic subsidence (Wilson 1999; Zampetti et al. 2004; Sattler et al. 2009; Wu et al. 2008; Xie et al. 2011). A $100 \mathrm{~m}$ high euphotic zone could have a large growth
Fig. 9 An overview of the backstripped tectonic subsidence curves. Three rapid subsidence episodes (see gray shade regions) between 65-32 Ma, 17-15 Ma, and $5 \mathrm{Ma}$-recent, are intermitted with two slow subsidence episodes. a subsidence curve in the Reed Bank Basin; b subsidence curve in the North Palawan Basin

potential of reefs and carbonate platforms, while shallow water carbonates would be drowned when the rate of increase of water depth is greater than the rate of carbonate accumulation (Schlager and Camber 1986). In the following section, we discuss the influence of these two factors on the formation of carbonate plarforms and reefs in the Reed Bank area.

\section{Cenozoic tectonics as a major controlling factor}

In the Reed Bank area, the geodynamic context was mainly controlled by the continental extension and by the opening of the South China Sea (Franke et al. 2008; Ding et al. 2011), leading to extensional or transtensional tectonics in
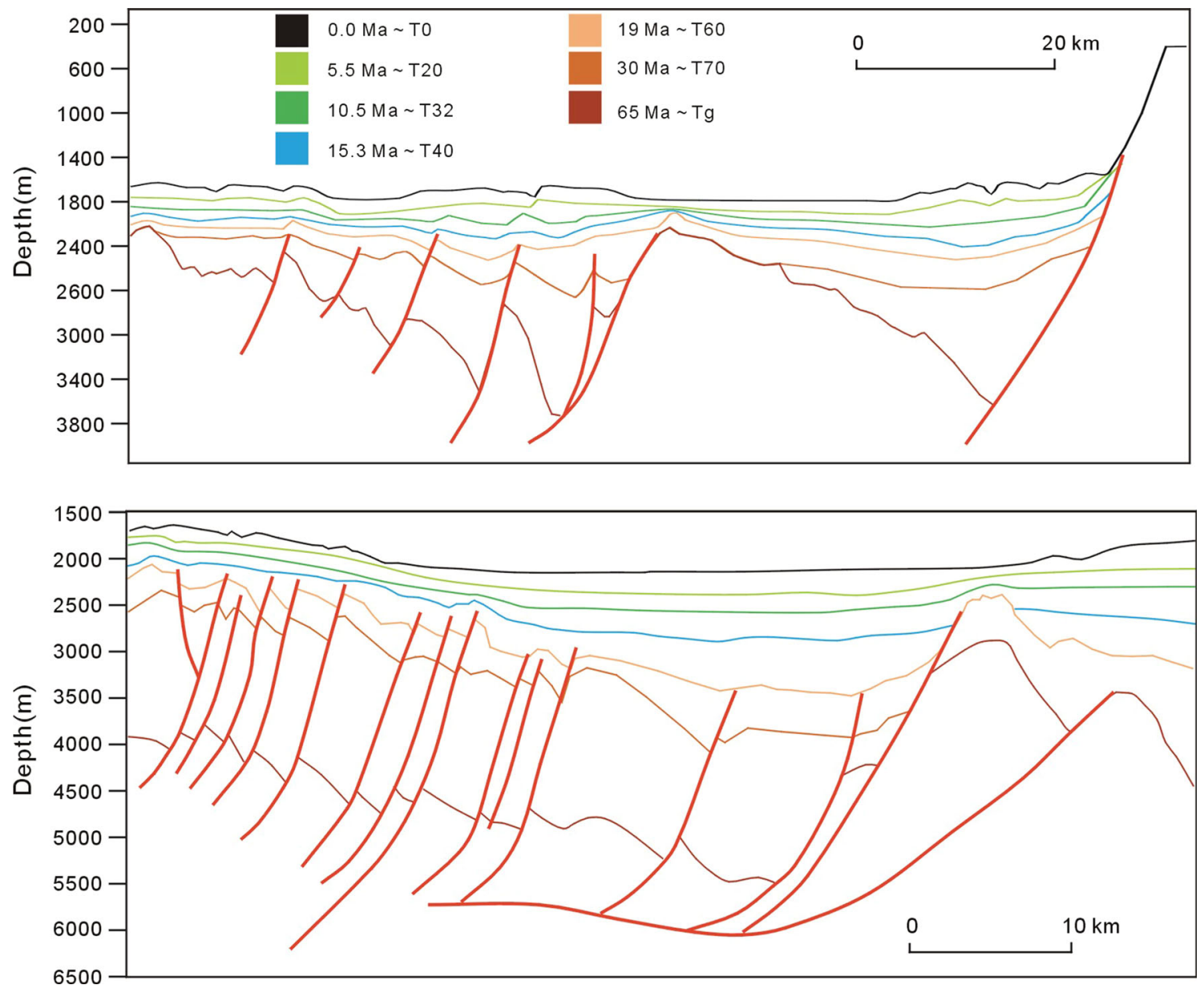

Fig. 8 Time-depth conversion of the geological interpretation for the tectonic subsidence measured in the area. a Reed Bank Basin; b West Palawan Basin. See Fig. 3 for the location 

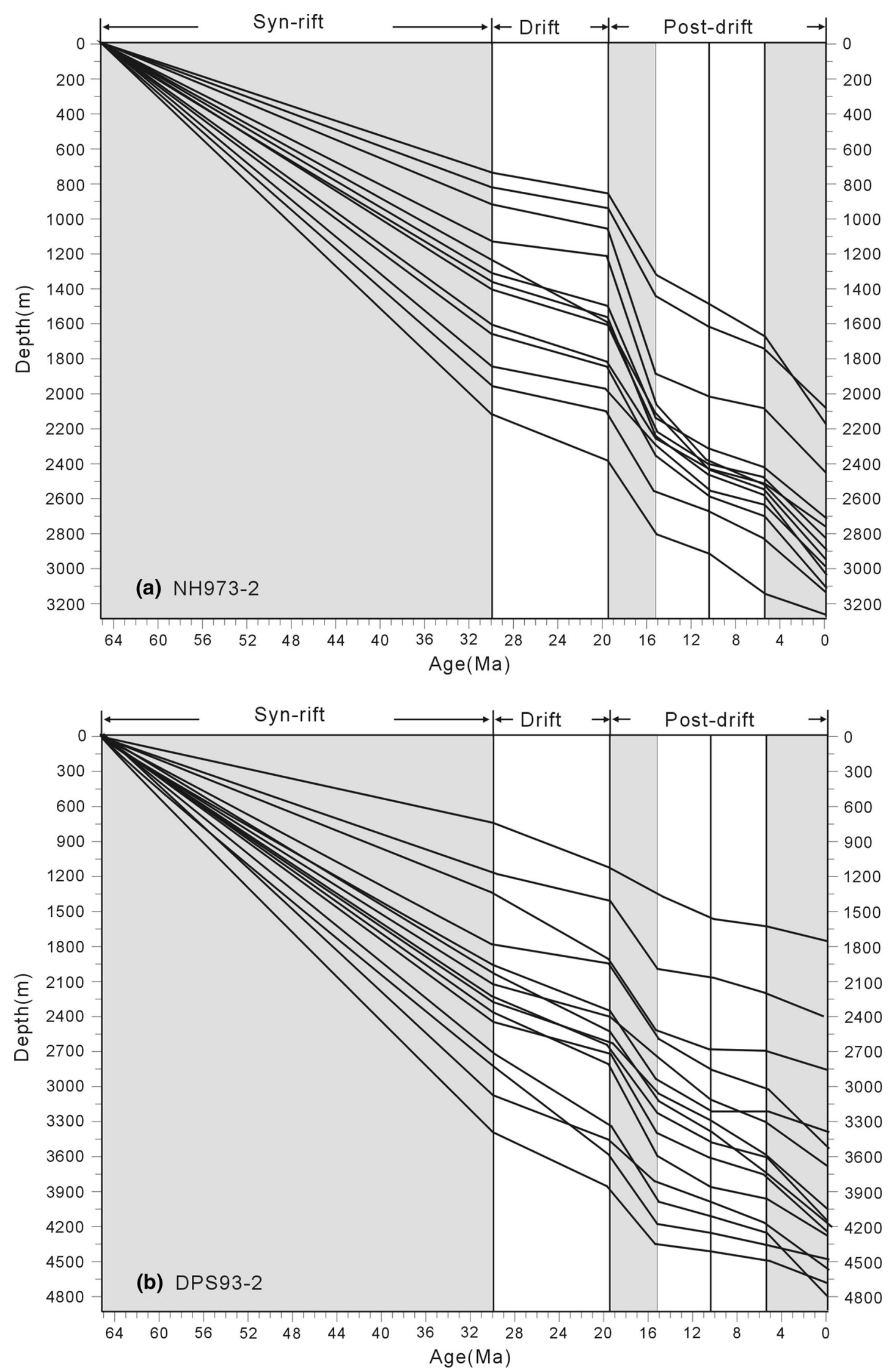
the marginal basins, that is, tectonics may trigger sedimentary events at a regional scale. The carbonates generally developed during the drifting stage of the South China Sea, corresponding with a slower subsidence.

The subsidence of rifted continental margins is explained by the mechanical and isostatic response to the lithospheric stretching (McKenzie 1978), and generally rapid thermal subsidence would happen after the continental break-up, when an initial seafloor spreading is driven by cooling and thickening of the asthenosphere. Early Miocene carbonates indicate that there was a delay of tectonic subsidence after the seafloor spreading, which has been proved by the calculated subsidence rates (Fig. 9). Such a temporary subsidence delay has also been widely reported from either magma poor passive continental margin like the Iberia-Newfoundland (Kusznir and Karner 2007; Péron-Pinvidic and Manatschal 2009), or magma rich passive margins, such as the North-eastern Atlantic margin (Clift 1997) and Pakistan volcanic margin (Claves et al. 2008). In this way, the continental margins subsides less than might be expected from the observed crustal thinning and resulting isostatic response.

This lack of tectonic subsidence may be the result of a number of possible processes. Since the thermal subsidence is driven by the lithospheric thickening, we suggest that the slow subsidence after break-up indicates a slow lithospheric growth, and that normal subsidence and lithospheric thickening does not occur until after $17 \mathrm{Ma}$. Reston (2009) argued that the effect of mantle serpentinization during rifting, or the addition of any igneous material at subcrustal level could result in permanent uplift. While we can exclude this mechanism, for the delayed tectonic subsidence is temporary, but not permanent.

After the Early Miocene the subsidence rate increased again and ceased the development of carbonate platforms, which were overlain by silty shales and siltstones. Franke et al. (2011) suggested another hypothesis, that the ongoing westward rifting of the southern continental margin might have prevented the region from subsiding.

Although this possibility could not be excluded, we prefer the opinion that secondary convection (first or major mantle convection happened in the oceanic basin) in the mantle beneath a rift in the continental margin may have eroded the lithosphere and caused the very slow lithospheric growth after the initial sea-floor spreading and for more than the following $10 \mathrm{Ma}$.

Numerical experiments have proved that as the major mantle convection occurred below the oceanic crust, a variation in lithospheric thickness of the continental margin will cause lateral temperature gradients, and thus induce secondary convection (Buck 1986; Faccenna and Becker 2010), or edge-driven convection (King and Anderson 1998). This convection beneath the passive rifts will result in the thinning of the adjacent lithosphere, controlling the uplift of the rift shoulders, as well as the decrease of the tectonic subsidence of the middle of the rift basin. This geodynamic model have been successfully applied in many cases, such as the rifted margin of Pakistan (Claves et al. 2008), or the Atlantic margin (Buck 1986; Wijk et al. 2008, 2010).

Ocean Bottom Seismographs have been positioned along the seismic reflection profile NH973-2. The crustal structure has been referred to a velocity model indicating a $21 \mathrm{~km}$ thick crust of the Reed Bank and a $12 \mathrm{~km}$ thick continental crust of the Reed Bank Basin and north Palawan Basin. The Moho depth gap is about $8 \mathrm{~km}$ (Ruan et al. 2012). Such a gap in the lithospheric thickness was likely to cause steep vertical temperature contrasts, and then induced a mantle convection under the rifted Reed Bank Basin, involving also the North Palawan Basin. According to the distribution of the carbonate platforms in the Reed Bank Basin and North Palawan Basin, we have estimated that this secondary mantle convection could have a range of 110-150 km between the Reed Bank and Palawan offshore. The theoretically expected lithospheric thickening could have been buffered by the simultaneous influx of warmer asthenosphere below the rift. This buffering of the subsidence is expected to decay or disappear as the lithosphere and asthenosphere adjust back to equilibrium point (Franke et al. 2013). After the cessation of seafloor spreading $(\sim 17 \mathrm{Ma})$, the asthenosphere under both the oceanic basin and continental margin cooled down, and the lithospheric growth increased. The whole area, including the Reed Bank area, experienced a quick thermal subsidence. The carbonate platform was drowned and stopped its development.

\section{Sea level changes}

The eustatic sea level changes have also been considered as one of the critical factor controlling the development of carbonate platform (Wilson 1999; Wilson et al. 2000; Ma et al. 2011). During a period of rising sea level, the carbonate platforms and reefs are considered to grow with a strong vertical and lateral aggradation, if tectonic environment is stable. On the other side, if the rising rate of sea level is much higher than the growth rate of carbonates, the carbonate platform and reefs grow with a strong vertical aggradation and then become rapidly drowned and died.

A sea level change curve of the South China Sea has been constructed based on biostratigraphically data of 50 wells on the northern continental margin (Pang et al. 2007). This eustatic curve has also been considered valid in the southern margin (Fig. 2). The South China Sea has experienced an overall rise of the relative sea level during the 


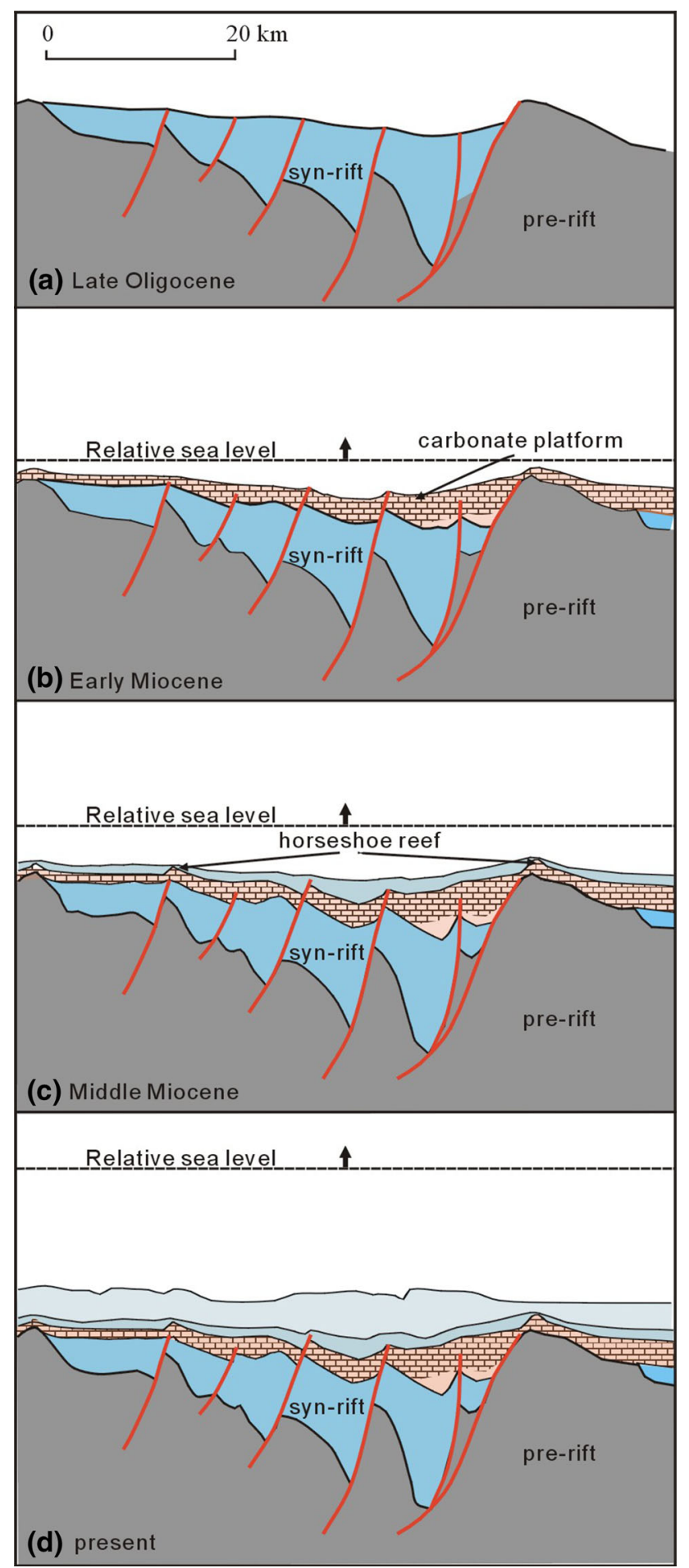

Fig. 10 Schematic model of the evolution and demise of the carbonate deposits in the Reed Bank area

Neogene, despite high frequency sea level fluctuations. During the Late Oligocene and the Early Miocene a slow rise of relative sea level occurred and the tectonics was relatively stable in this stage, favouring the development of carbonate platforms (Fig. 10a, b).
After the Early Miocene, a quick subsidence occurred in the Reed Bank Basin, while the relative sea level continued to rise, resulting in the drowning of carbonate platforms developed in lowstand areas (Fig. 10c). The carbonate buildups upon structural highs survived, but experienced an overall backstepping of carbonate facies, controlling a decrease in the extension of the carbonate platform. After the Middle Miocene the Reed Bank area was dominated by a hemipelagic abyssal sedimentary environment (Fig. 10d).

\section{Conclusion}

Two multi-channel seismic profiles in the south-eastern continental margin of the South China Sea have been interpreted in detail. Seismic reflection profiles calibrated through well data have shown regionally distributed carbonates as carbonate platforms and reefs, which can be traced by a striking unconformity corresponding with a strong and continuous reflector (T60 unconformity). T60 is a regional unconformity separating the rifting infill from draping deposits corresponding to the drifting phase in the study area. We set a timing of $\sim 20 \mathrm{Ma}$ for T60. After an erosional/non-depositional hiatus lasting 3-4 m.y., the corresponding unconformity may represent the end of sea floor spreading (17 Ma) in the South China Sea.

Relict reefs developing on some structural highs continued to deposit since the Middle Miocene. Well data coupled with dredges on carbonate structural highs proved that the most carbonates started their growth since the Late Oligocene, thus a time consistent existed between the development of these shallow water carbonates and the South China Sea's opening, i.e. the Reed Bank area has been in shallow water conditions for more than 10 m.y. This indicates a delay in the tectonic subsidence with respect to the theoretical subsidence expected from the observed crustal thinning and resulting isostatic response. The reconstruction of the tectonics subsidence proved this slow subsidence rate during the drifting stage (32-17 Ma), if compared with the syn-rifting one (65-32 Ma). The rate accelerated again after the end of sea floor spreading and continued up to $15 \mathrm{Ma}$, indicating a quick thermal subsidence and a sharp change of sedimentary environments.

The slow tectonic subsidence after the break-up and the following $10 \mathrm{~m}$.y. has been explained as reflecting a period of minimal lithospheric growth, probably due to the secondary mantle convection under the rift of the Reed Bank area. Large-scale mantle convection under the oceanic basin and the lateral temperature gradients under the continental margin might have triggered this local mantle convection under the continental margin.

A gentle rise of relative sea level, and the relative stable tectonics during the Late Oligocene and Early Miocene 
both favoured the development of the carbonates. While continued rising sea level and a quick subsidence after Early Miocene make the carbonate platform die, except some reefs continued their life upon some structural highs, even to recent, such as the Reed Bank.

Acknowledgments We want to thank Zhen Sun and two anonymous reviewers for their helpful reviews that permitted to improve the manuscript. Peter Clift and Dieter Franke are thanked for the stimulating discussions on this paper. This work was financially supported by the National Natural Science Foundation of China (Nos. 41376066, 91028006), the Scientific Research Fund of the SIO, SOA (No. JT1202), and the Public Science and Technology Research Funds Project of Ocean (No. 201205003).

Open Access This article is distributed under the terms of the Creative Commons Attribution License which permits any use, distribution, and reproduction in any medium, provided the original author(s) and the source are credited.

\section{References}

Bathurst RGC (1971) Carbonate sediments and their diagenesis. Elsevier, Amsterdam

Briais A, Patriat P, Tapponnier P (1993) Updated interpretation of magnetic anomalies an seafloor spreading stages in the South China Sea: implications for the tertiary tectonics of Southeast Asia. J Geophys Res 98:6299-6328

Buck WR (1986) Small-scale convection induced by passive rifting: the cause for uplift of rift shoulders. Earth Planet Sci Lett $77: 362-372$

Chen L (2014) Stretching factor estimation for the long-duration and multi-stage continental extensional tectonics: application to the Baiyun Sag in the northern continental margin of the South China Sea. Tectonophysics 611:167-180

Claves G, Clift PD, Inam A (2008) Anomalous subsidence on rifted volcanic margin of Pakistan: no influence from Deccan plume. Earth Planet Sci Lett 272:231-239

Clift PD (1997) Temperature anomalies under the Northeast Atlantic rifted volcamic margins. Earth Planet Sci Lett 146:195-211

Clift P, Lin J (2001) Preferential mantle lithospheric extension under the South China Sea margin. Mar Petrol Geol 18:929-944

Clift P, Lee GH, Duc NA, Barckhausen U, Long HV, Sun Z (2008) Seismic reflection evidence for a Dangerous Grounds miniplate: no extrusion origin for the South China Sea. Tectonics 27:TC3008. doi:10.1029/2007TC002216

Cullen A, Reemst P, Henstra G, Gozzard S (2010) Rifting of the South China Sea: new perspective. Petrol Geosci 16:273-282

Ding WW, Li JB, Li MB (2011) Seismic stratigraphy, tectonic structure and extension model across the Reed Bank Basin in the South China Sea: evidence from NH973-2 multi-channel seismic profile. J Earth Sci 36(5):895-904

Ding WW, Franke D, Li JB, Steuer S (2013) Seismic stratigraphy and tectonic structure from a composite multi-channel seismic profile across the entire Dangerous Grounds, South China Sea. Tectonophysics 582:162-176

Ding WW, Li JB, Dong CZ, Fang YX, Tang Y, Fu J (2014) Carbonate platforms in the Reed Bank area, South China Sea: seismic characteristics, development and controlling factors. Energy Explor Exploit 32(1):243-261

Faccenna C, Becker TW (2010) Shaping mobile belts by small-scale convection. Nature 465:602-605
Franke D, Barckhausen U, Heyde I, Tingay M, Ramli N (2008) Seismic images of a collision zone offshore NWSabah/Borneo. Mar Petrol Geol 25:606-624

Franke D, Barckhausen U, Baristeas N, Engels M, Ladage S, Lutz R, Montano J, Pellejera N, Ramos EG, Schnabel M (2011) The continent-ocean transition at the southestern margin of the South China Sea. Mar Petrol Geol 28:1187-1204

Franke D, Savva D, Pubellier M, Steuer S, Mouly B, Auxietre J, Meresse F (2013) The final rifting evolution in the South China Sea. Mar Petrol Geol. doi:10.1016/j.marpetgeo.2013.11.020

Fyhn MBW, Boldreel LO, Nielsen LH (2009) Geological development of the Central and South Vietnamese margin: implications for the establishment of the South China Sea, Indochinese escape tectonics and Cenozoic volcanism. Tectonophysics 478:184-214

Fyhn MBW, Boldreel LO, Nielsen LH, Giang TC, Nga LH, Hong NTM, Nguyen ND, Abatzis I (2013) Carbonate platform growth and demise offshore Central Vietnam: effects of Early Miocene transgression and subsequent onshore uplift. J Asian Earth Sci $76: 152-168$

Groetsch J, Al-Jelani O, Al-Mehairi Y (1998) Intergrated reservoir characterization of a giant Lower Cretaceous oil field, Abu Dhabi, U.A.E. Society of Petroleum Engineers, SPE, 49454

Hazebroek HP, Tan DNK (1993) Tertiary tectonic evolution of the NW Sabah continental margin. Bull Geol Soci Malaysia $33: 195-210$

Hinz K, Schlueter HU (1985) Geology of the Dangerous Grounds, South China Sea, and the continental margin off southwest Palawan: results of SONNE Cruises SO-23 and SO-27. Energy 10(3/4):297-315

Hinz K, Fritsch J, Kempter EHK (1989) Thrust tectonics along the continental margin of Sabah, Northwest Borneo. Geol Rundsch 78:705-730

Holloway NH (1982) North Palawan-Philippines block: its relation to Asian mainland and role in evolution of South China Sea. AAPG Bull 66(9):1355-1383

Hutchison CS (2004) Marginal basin evolution: the southern South China Sea. Mar Petrol Geol 21:1129-1148

Hutchison CS (2010) The North-West Borneo trough. Mar Geol 271:32-43

Hutchison CS, Vijayan VR (2010) What are the Spratly Islands? J Asian Earth Sci 39(5):371-385

Hutchison CS, Bergman SC, Swauger DA, Graves JE (2000) A Miocene collisional belt in north Borneo: uplift mechanism and isostatic adjustment quantified by thermochronology. J Geol Soc Lond 157:783-793

King SD, Anderson DL (1998) Edge-driven convection. Earth Planet Sci Lett 160:289-296

Kudrass HR, Wiedicke M, Cepeck P, Kreuser H, Muller P (1986) Prequaternary rocks dredged from the South China Sea (Reed Bank area) and Sulu Sea, during Sonne Cruises in 1982-1983 and their significance for the plate tectonic reconstructions. Mar Petrol Geol 3:19-30

Kusznir N, Karner G (2007) Continental lithospheric thinning and breakup in response to upwelling divergent mantleflow: application to the Woodlark, Newfoundland and Iberia margins. In: Karner GD, Manatschal G, Pinheiro LM (eds) Imaging, mapping and modelling continental lithosphere extension and breakup. Geological Society of London, Special Publication, London, pp 389-419

Lees A, Buller AT (1972) Modern temperature water and warm water shelf carbonate sediments contrasted. Mar Geol 40:1767-1773

Levell BK (1987) The nature and significance of regional unconformities in the hydrocarbon-bearing Neogene sequences offshore West Sabah. Geol Soc Malaysia Bull 21:55-90

Lin J, Xu X, Li CF, Sun Z, Zhu J, Zhou ZY, Qiu N (2013) First highresolution near-seafloor survey of magnetic anomalies of the 
South China Sea. AGU Fallmeeting, OS23E-01. http://agu-fm13.abstractcentral.com

Ma YB, Wu SG, Lv FL, Dong DD, Sun QL, Lu YT, Gu MF (2011) Seismic characteristics and development of the Xisha carbonate platforms, northern margin of the South China. J Asian Earth Sci 40:770-783

Madden RHC, Wilson MEJ (2013) Diagenesis of a SE Asian Cenozoic carbonate platform margin and its adjacent basinal deposits. Sed Geol 286-287:20-38

McKenzie D (1978) Some remarks on the development of sedimentary basins. Earth Planet Sci Lett 40:25-32

Pang X, Chen CM, Peng DJ, Zhou D, Sun Z (2007) The Pearl River deep-water fan system and petroleum in South China Sea. Science Press, Beijing 147

Péron-Pinvidic G, Manatschal G (2009) The final rifting evolution at deep magmapoor passive margins from Iberia-Newfoundland: a new point of view. Int J Earth Sci 98:1581-1597

Qiu XL, Zhao MH, Ao W, Lu CC, Hao TY, You Q (2011) OBS survey and crustal structure of the Southwest Sub-basin and Nansha Block, South China Sea. Chin J Geophys 54(12): 3117-3128

Reading HG (1978) Sedimentary environments and facies. Blackwell Scientific, Elsevier New York, pp 557, ISBN 0-444-00276-6

Reston TJ (2009) The extension discrepancy and syn-rift subsidence deficit at rifted margins. Petrol Geosci 15:217-237

Ruan AG, Niu XW, Qiu XL, Li JB, Wu ZL, Zhao MH (2011) A wide angle ocean bottom seismometer profile across Liyue Bank, the southern margin of South China Sea. Chin J Geophys 54(12):3139-3149

Ruan AG, Niu XW, Qiu XL, Li JB, Wu ZL, Zhao MH, Wei XD (2012) A wide angle ocean bottom seismometer profile across Liyue Bank, the southern margin of South China Sea. Chin J Geophys 54(12):3139-3149

Sales AO, Jacobsen EC, Morado AA, Benavidez JJ, Navarro FA, Lim AE (1997) The petroleum potential of deep-water northwest Palawan Block GSEC 66. J Asian Earth Sci 15(2-3):217-240

Sattler U, Immenhauser A, Schlager W, Zampetti V (2009) Drowning history of a Miocene carbonate platform (Zhujiang Formation, South China Sea). Sediment Geol 219:318-331

Schlager W (1989) Drowning unconformities on carbonate platforms. In: Crevello PD, Wilson JL, Sarg JF, Read F (eds) Controls on carbonate platform and basin development. SEPM Special Publication 44, pp 15-25

Schlager W, Camber O (1986) Submarine slope angles, drowning unconformities and self-erosion of limestone escarpments. Geology 14:762-765

Schlueter HU, Hinz K, Block M (1996) Tectono-stratigraphic terranes and detachment faulting of the South China Sea and Sulu Sea. Mar Geol 130:39-78

Sclater JG, Christie PA (1980) Continental stretching: an explanation of the post Mid-Cretaceous subsidence of the central North Sea basin. J Geophys Res 85:3711-3739

Shipboard Scientific Party (2000) Leg 184 summary: exploring the Asian Monsoon through drilling in the South China Sea. In: Wang P, Prell W, Blum P (eds) In: Proceedings of ODP, Initial results. IODP, College Station, TX, 1-77

Steckler MS, Watts AB (1978) Subsidence of the Atlantic-type continental margin off New York. Earth Planet Sci Lett 41:1-13

Steuer S, Franke D, Meresse F, Savva D, Pubellier M, Auxietre J, Aurelio MA (2013) Oligocene-Miocene carbonates and their role for constraining the rifting and collision history of the Dangerous Gounds, South China Sea. Mar Petrol Geol 76:412-427

Sun SQ, Esteban M (1994) Paleoclimatic controls on sedimentation diagenesis and reservoir quality: lessons from Miocene carbonates. AAPG Bull 78:519-543
Sun Z, Zhong Z, Keep M, Zhou D, Cai D, Li X, Wu S, Jiang J (2009) $3 \mathrm{D}$ analogue modeling of the South China Sea: a discussion on breakup pattern. J Asian Earth Sci 34:544-556

Tapponier P, Peltzer G, Armijo R (1986) On the mechanism of collision between India and Asia. In: Coward MP, Ries AC (eds) Collision tectonics. Geological Society, London, Special Publications, 19, 115-157

Taylor B, Hayes DE (1980) The tectonic evolution of the South China Basin. In: Hayes DE (ed) The tectonic and geologic evolution of Southeast Asian Seas and Islands, part 1. Am Geophys Union Geophys Monogr, 89-104

Taylor B, Hayes DE (1983) Origin and history of the South China Sea. In: Hayes DE (ed) The tectonics and geological evolution of Southeast Asia Seas and Islands, vol 23. American Geophysical Union Monography, 89-104

Tyrell WWJ, Christian HEJ (1992) Exploration history of Liuhua 11-1 Field, Pearl River Mouth Basin, China. AAPG Bull 76:1209-1223

Wijk JV, Hunen JV, Goes S (2008) Small-scale convection during continental rifting: evidence from the Rio Grande rift. Geology 36(7):575-578

Wijk JV, Baldridge WS, Hunen JV, Goes S (2010) Small-scale convection at the edge of the Colorado Plateau: implications for topography, magmatism, and evolution of Proterozic lithosphere. Geology 38(7):611-614

Williams HH (1997) Play concepts-northwest Palawan, Philippines. J Asian Earth Sci 15:251-273

Wilson JL (1975) Carbonate facies in geologic history. Springer, Berlin

Wilson MEJ (1999) Prerift and synrift sedimentation during early fault segmentation of a Tertiary carbonate platform, Indonesia. Mar Petrol Geol 16:825-848

Wilson MEJ, Bosence DWJ, Limbong A (2000) Tertiary syntectonic carbonate development in Indonesia. Sedimentology 47:183-201

Wu SG, Yuan SQ, Zhang GC, Ma YB, Mi LJ, Xu N (2008) Seismic characteristics of a reef carbonate reservoir and implications for hydrocarbon exploration in deepwater of the Qiongdongnan Basin, northern SCS. Mar Petrol Geol 26(6):817-823

Xie XN, Zhang C, Ren J, Yao B, Wang L, Chen H, Kang B (2011) Effects of distinct tectonic evolutions on hydrocarbon accumulation in northern and southern continental marginal basins of South China Sea. Chin J Geophys 54(12):3280-3291

Xu GQ, Lv BQ, Wang HG (2002) Drown event research: insight from Cenozioc carbonate platform in northern SCS. J Tongji Univ 30(1):35-40

Yan P, Liu HL (2004) Tectonic-stratigraphic division and blind fold structures in Nansha waters, South China Sea. J Asian Earth Sci 24:337-348

Yao YJ, Liu HL, Yang CP, Han B, Tian JJ, Yin ZX, Ge JL, Xu QY (2012) Characteristics and evolution of Cenozoic sediments in the Liyue Basin, SE South China Sea. J Asian Earth Sci 60:114-129

Yumul Jr GP, Dimalanta CB, Tamayo Jr RA, Maury RC (2003) Collision, subduction and accretion events in the Philippines: a synthesis. Island Arc 12:77-91

Zampetti V, Schlager W, Konijnenburg JH, Everts AJ (2004) Architecture and growth history of a Miocene carbonate platform from 3D seismic reflection data; Luconia province, offshore Sarawak, Malaysia. Mar Petrol Geol 21:517-534

Zhao ZX, Sun Z, Wang ZF, Sun ZP, Liu JB, Wang ZW, Sun LT (2013) The dynamic mechanism of postrift accelerated subsidence in Qiongdongnan Basin, northern South China Sea. Mar Geophys Res 34:295-308

Zhou D, Ru K, Chen HZ (1995) Kinematics of Cenozoic extension on the South China Sea continental margin and its implications for the tectonic evolution of the region. Tectonophysics 251:161-177 